Journal of Applied Pharmaceutical Science Vol. 5 (08), pp. 147-151, August, 2015

Available online at http://www.japsonline.com

DOI: $10.7324 /$ JAPS.2015.50823

ISSN 2231-3354 (cc)) BY-NC-SA

\title{
Radioprotective Properties of Chitosan on Cultured Human Lymphocytes against Electron Beam Radiation
}

\author{
Shama Rao, Sukanya Shetty*, Suchetha Kumari Nalilu, Madhu LN \\ Department of Biochemistry, K.S.Hegde Medical Academy, Nitte University, Deralakatte, Mangalore, India \\ PG Department of Biochemistry, St. Aloysius College, Mangalore
}

\section{ARTICLE INFO \\ Article history: \\ Received on: 20/04/2015 \\ Revised on: $24 / 05 / 2015$ \\ Accepted on: 12/06/2015 \\ Available online: $28 / 08 / 2015$}

Key words:

Radioprotection, Electron

Beam Radiation, Chitosan

\begin{abstract}
The radioprotective effects of naturally occurring compounds have been investigated in vitro and in vivo considering their pharmacological role in prevention and treatment of cancer. Chitosan (CS) is a naturally occurring polymer that has been increasing attention in pharmaceutical and biomedical applications because of its biocompatibility, biodegradability, nontoxicity, cationic properties and bio adhesive characters. Lymphocytes were treated with different concentrations of chitosan for the period of 2 and $24 \mathrm{hr}$. Cell viability was determined by tryphan blue dye exclusion assay, single strand DNA damage by alkaline comet assay and in vitro cytogenetic damages were evaluated by micronucleus assays. Treatment of lymphocytes with chitosan before and after the exposure to $4 \mathrm{~Gy}$ of electron beam radiation (EBR) resulted in the reduction of percentage of tail DNA in comet from $24.06 \pm 3.92$ to $6.94 \pm 1.34$ and olive tail moment (OTM) was reduced from $25.34 \pm 3.09$ to $10.66 \pm 0.23$ at $10 \mu \mathrm{g} / \mathrm{mL}$ concentration. The micronucleus formation in radiation control group $(13.75 \pm 0.37)$ was significantly reduced in chitosan pretreated groups $7.63 \pm 1.02$. Cells treated with chitosan at $10 \mu \mathrm{g} / \mathrm{mL}$ showed maximum viability after exposure to EBR. Present investigation data proves the protective effect of CS against EBR induced damage in lymphocyte. However, increase in concentration above $100 \mu \mathrm{g} / \mathrm{mL}$ though resulted in higher protection, an increased cell toxicity was also noticed.
\end{abstract}

\section{INTRODUCTION}

The recent radiation biology research is mainly focused on the identification and development of non toxic and effective radioprotective compounds that can reduce the effect of radiation. These compounds may perhaps potentially protect the biological system against the chromosomal damage, mutation, variation in the immune system which acts through the generation of free radicals (Jagetia et al., 2002). Due to increased application of ionizing radiation in human life, mainly in radiotherapy of cancer, food processing, agriculture, industry, power generation and nuclear warfare which possesses both practical and inauspicious effect on human life (Thomas et al., 2006). To overcome the side effects of radiation there is a need to develop potent radioprotector which possess non-toxicity, higher radioprotection at lower concentration and most efficient. Investigations are going on towards the development of ideal

\footnotetext{
* Corresponding Author

Sukanya Shetty, Department of Biochemistry, K.S.Hegde Medical

Academy, Nitte University, Deralakatte, Mangalore, India

Email: drsukanyashetty99@gmail.com
}

radioprotector, but other than Amifostine and few other compounds like sodium selenite identified as novel radioprotector today or in clinical use. Beta-carotene, tocopherol, Vitamin C, Vitamin A exhibiting free radical scavenging activity and some extent of radioprotection (Cherupally et al., 2001), but which are not yet considered for clinical trial. Chitosan is a deacetylated derivative of chitin polymer, which is the primary constituent of crustacean shells, insect cuticles and fungal cell wall (Herrera et al., 2003). Chitosan consists of three types of reactive functional groups, an amino/acetamido group at $\mathrm{C}_{2}, \mathrm{C}_{3}$ as well as both primary and secondary hydroxyl groups at $\mathrm{C}_{6}$ positions, which are biocompatible, antibacterial, polyelecrolyte and biodegradable in nature (Xia et al., 2003). In present study focused to investigate the radioprotective property of chitosan at different concentrations in cell culture model.

\section{MATERIALS AND METHOD}

Chitosan (CAS No.9012-76-4) was used in this study was shrimp origin of high molecular weight purchased from Sigma Aldrich. 


\section{Lymphocyte isolation and culture}

$1 \mathrm{ml}$ venous blood was collected from healthy, nonsmoking, non-alcoholic volunteer by vein puncture. The study has been approved by Central Ethical committee, Nitte University (NU/CEC/PhD-73/2013). Lymphocytes were separated using lymphocyte separation media (LSM-Himedia). $1 \mathrm{ml}$ of fresh EDTA blood mixed with equal volume of phosphate buffered saline (PBS), which was overlaid on $1 \mathrm{ml}$ of LSM. Lymphocytes were separated by density gradient centrifugation. Separated lymphocytes were washed twice with PBS and cells were suspended in minimum volume of RPMI-1640 (Himedia) and counted. $1 \times 10^{6}$ cells $/ \mathrm{ml}$ cultured in RPMI medium supplemented with $6 \mu \mathrm{g} / \mathrm{ml}$ Phytohemagglutinin and $15 \%$ Fetal Bovine Serum (FBS) at $37^{\circ} \mathrm{C}$ in a $5 \% \mathrm{CO} 2$ incubator.

\section{Determination of EBR $\mathbf{L D}_{\mathbf{5 0}}$}

The cultured lymphocytes were exposed to EBR at 212Gy. The EBR exposed cells were maintained in RPMI medium for 24hous. After 2 and 24hours the cell viability was determined by Trypan blue dye exclusion assay to analyze the immediate response and late response of the cells towards radiation exposure.

\section{Experimental design}

Present study was carried out in 5 groups, Group 1: Control (Cells without radiation) Group 2: Radiation control (RC: cells exposed 4Gy EBR) Group 3: Drug control (cells treated with only chitosan), Group 4: Pre-treatment group (cell treated with chitosan before EBR exposure), Group 5: Post treatment group (cells treated with chitosan after EBR exposure).

\section{Cell viability assay}

Cell viability was measured by trypan blue dye exclusion method. Lymphocytes were mixed with equal volume of $0.4 \%$ trypan blue dye for 3 minutes and cells were counted using haemocytometer. Viable and dead cells were scored under the microscope.

\section{Analysis of DNA damage by comet assay}

The alkaline comet assay was performed basically as described by Tice et al., 1991. Electrophoresis, which allowed for fragmented DNA migration was carried out for $20 \mathrm{~min}$ at $25 \mathrm{~V}$ and $300 \mathrm{~mA}$. After electrophoresis, the slides were neutralized with 0.4 $\mathrm{M}$ Tris, $\mathrm{pH} 7.4$, stained with $50 \mu \mathrm{L}$ of ethidium bromide (20 $\mu \mathrm{g} / \mathrm{mL}$ ) and analyzed with a fluorescence microscope (Olympus. 40x objective).

The extent of DNA damage was assessed from the DNA migration distance, which was derived by subtracting the diameter of the nucleus from the total length of the comet. Fifty randomly selected cells were examined for each replicate, for each sample or subject. The quantification of the DNA strand breaks of the stored images was performed using Comet score software by which the percentage of DNA in the tail, tail length and OTM could be obtained directly.

\section{DNA diffusion assay}

To estimate the percentage of apoptotic cells, DNA diffusion assay was performed as described by Singh et al., 2000. The percentage of apoptosis measured by counting the apoptotic cells and normal cells. In brief slide preparation: base layer $50 \mu \mathrm{l}$ of agarose smeared and air dried. 50 $\mu$ l of cell-agarose suspension was layered over the base layer and covered with coverslip. Slides were lysed by treating with alkaline lysing solution further slides were neutralized by treating with DNA precipitating solution for 30 minutes. This step repeated 2 times. Finally slides were stained with $20 \mu \mathrm{g} / \mathrm{ml}$ ethidium bromide and slides were analyzed under florescent microscope (Olympus).

\section{In vitro Micronucleus assay}

In vitro micronucleus assay was performed basically described by French 2000. Lymphocytes were separated and cultured under standard conditions supplemented with $6 \mu \mathrm{g} / \mathrm{ml}$ Phytohaemagglutinin (PHA). Cultured lymphocytes were exposed to sublethal dose of EBR then then after 44 hour Cytochelasin B, $6 \mu \mathrm{g} / \mathrm{ml}$ was added and cells were cultured total 72 hours. After 72 hour of incubation cells were harvested by by centrifugation $700 \mathrm{rpm}, 6$ minutes. From each sample 2 slides were made air dried, fixed in methanol (15 min) and dried again before staining. Slides were stained in $4 \%$ Giemsa stain for 10 minutes.

\section{Statistical analysis}

The results were expressed as mean \pm standard deviation. Comparison between the control and treated groups were done by analysis of variance (ANOVA) followed by Tukey's test. The comparison between different time intervals was performed by One Way ANNOVA followed by Bonferroni test. In all these test criterion for statistical significance was $\mathrm{P}<0.05$.

\section{RESULTS}

\section{Radiation Dose Fixation for Lymphocytes}

Cultured lymphocytes were subjected to different doses of EBR (2 to $12 \mathrm{~Gy}$ ) to assess the $\mathrm{LD}_{50}$. The cell viability was reduced upto $50.35 \pm 0.65$ percent at 24 hour for $6 \mathrm{~Gy}$ EBR dosage. The calculated LD50 value was found to be 5.01Gy of EBR dosage for cultured lymphocytes. So the further studies were carried with a sub lethal dose of $4 \mathrm{~Gy}$ (Table 1). The number of apoptotic lymphocytes were significantly $(\mathrm{P}<0.05)$ increased with increase in the radiation dosage. But there was no significant difference observed when apoptotic cell percentage was compared between different time duration (Table 2). The comet assay and micronucleus test result shows the progression of DNA damage in a dose dependent manner (Figure 1 and 2, Table 3). 


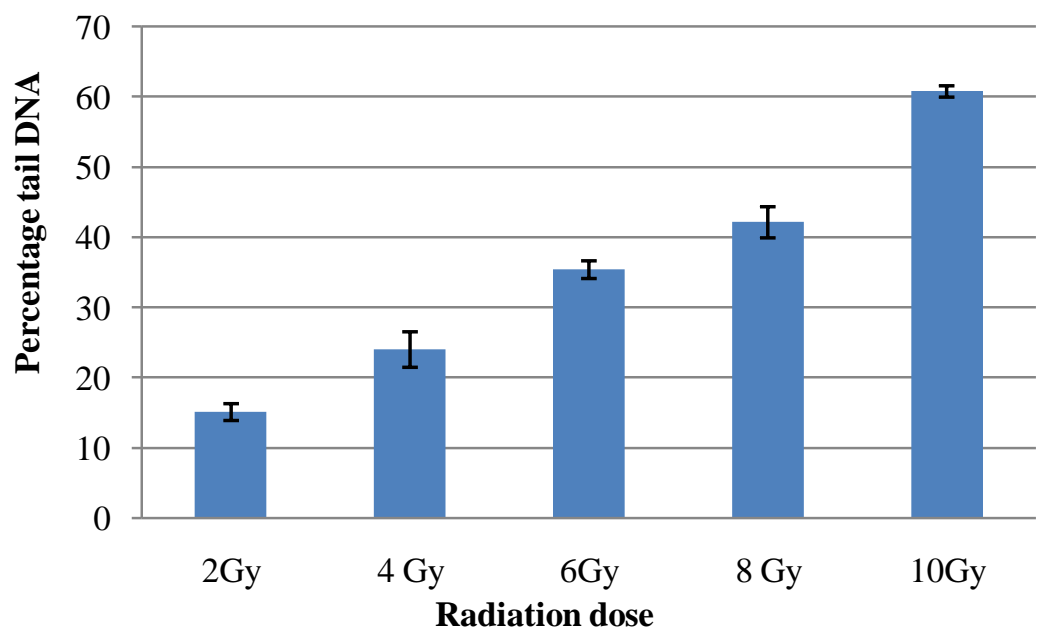

Fig. 1: Degree of DNA damage in cultured lymphocytes after exposing to different doses of radiation. Results expressed in Percentage tail DNA (P<0.05).

Table 1: Percentage of cell viability in cultured lymphocytes after exposing to different doses of radiation.

\begin{tabular}{cccccccc}
\hline & Control & 2Gy & 4Gy & 6Gy & 8Gy & 10Gy & 12Gy \\
\hline $\mathbf{2 h r}$ & $97.00 \pm 2.00$ & $87.35 \pm 0.77$ & $76.34 \pm 1.23$ & $55.34 \pm 0.34$ & $36.98 \pm 0.98$ & $1.18 \pm 0.01$ & 0.00 \\
$\mathbf{2 4 h r}$ & $98.14 \pm 1.10$ & $85.39 \pm 0.93$ & $75.98 \pm 1.98$ & $50.35 \pm 0.65$ & $34.45 \pm 0.56$ & 0.00 & 0.00 \\
\hline
\end{tabular}

Results are expressed as Mean \pm SD. $\mathrm{P}<0.05$ considered to be significant. $\mathrm{P}<0.05$.

Table 2: Percentage of apoptosis in cultured lymphocytes after exposing to different doses of radiation.

\begin{tabular}{ccccccc}
\hline & Control & $\mathbf{2 G y}$ & $\mathbf{4 G y}$ & $\mathbf{6 G y}$ & $\mathbf{8 G y}$ \\
\hline $\mathbf{2 h r}$ & $0.56 \pm 0.14$ & $25.82 \pm 0.34$ & $27.22 \pm 0.87$ & $39.23 \pm 0.87$ & $58.36 \pm 1.09$ & $67.34 \pm 3.18$ \\
$\mathbf{2 4 h r}$ & $0.91 \pm 0.09$ & $30.24 \pm 0.99$ & $33.87 \pm 0.34$ & $40.87 \pm 0.89$ & $58.92 \pm 1.18$ \\
\hline
\end{tabular}

$\mathrm{P}<0.05$.

Table. 3: Percentage of Micronucleated Lymphocytes after exposing to different doses of radiation.

\begin{tabular}{cc}
\hline Radiation Dose & Percentage Micronucleus \\
\hline Control & $2.3 \pm 0.239$ \\
2Gy & $6.65 \pm 0.24$ \\
6Gy & $13.15 \pm 0.75$ \\
8Gy & $16.62 \pm 0.28$ \\
$10 \mathrm{~Gy}$ & $21.60 \pm 0.42$ \\
\hline
\end{tabular}

Table 4: Percentage of viable cells in lymphocytes were treated with various concentrations of chitosan.

\begin{tabular}{|c|c|c|c|c|c|}
\hline & Untreated & $10 \mu \mathrm{g} / \mathrm{mL}$ & $50 \mu \mathrm{g} / \mathrm{mL}$ & $100 \mu \mathrm{g} / \mathrm{mL}$ & $150 \mu \mathrm{g} / \mathrm{mL}$ \\
\hline $2 \mathrm{hr}$ & $97.00 \pm 2.00$ & $98.32 \pm 4.32$ & $82.41 \pm 9.63$ & $59.43 \pm 8.62$ & $40.32 \pm 5.57$ \\
\hline $24 \mathrm{hr}$ & $98.14 \pm 1.10$ & $99.98 \pm 3.41$ & $80.34 \pm 1.69$ & $55.47 \pm 3.98$ & $35.46 \pm 3.41$ \\
\hline
\end{tabular}

\section{Chitosan Dosage Fixation for Cultured Lymphocytes}

At higher concentration (100 and $150 \mu \mathrm{g} / \mathrm{mL})$ of chitosan the cell viability was reduced upto $55.47 \pm 3.98$ and $35.46 \pm 3.41$ within 24 hour respectively. According to the probit analysis the calculated $\mathrm{LC}_{50}$ value was $100 \mu \mathrm{g} / \mathrm{mL}$. So further radioprotective studies were carried at sub lethal concentration $(10$ and $50 \mu \mathrm{g} / \mathrm{mL})$ of chitosan (Table 4).

\section{Effect of chitosan pre-treatment on EBR exposed lymphocytes}

Treatment of irradiated human lymphocyte with chitosan inhibited the formation of apoptotic cells, as revealed by significant increase in the cell viability and reduction in the frequency of apoptosis. The maximal reduction of apoptosis was observed at 24hour post exposure in cells treated with $10 \mu \mathrm{g} / \mathrm{mL}$ of chitosan (Table 5). Results have shown that treatment of chitosan significantly $(\mathrm{P}<0.05)$ reduce the frequency of micronuclei in lymphocyte exposed to 4Gy EBR. The percentage of micronucleated cells were reduced upto $7.63 \pm 1.02$ when compared with radiation control $(13.15 \pm 0.75)$ (Table 6). Alkaline comet assay results showed maximum amount of ssDNA damage at $4 \mathrm{hr}$ after the EBR exposure. Percentage of DNA in tail was reduced upto 3.89 and 3.17 folds at 10 and $50 \mu \mathrm{g} / \mathrm{mL}$ concentration of chitosan treatment when compared to $4 \mathrm{hr}$ radiation control group. Similar data obtained for OTM, which indicates the protective effect of GE against EBR induced ssDNA damage (Figure 3 and 4).

Percentage of viable cells were significantly $(\mathrm{P}<0.001)$ reduced in 4Gy irradiated group when compared to untreated group. The viability of the cells was found to be enhanced in drug treated group at both 2 and $24 \mathrm{hr}$ after the EBR exposure (Table 7). 


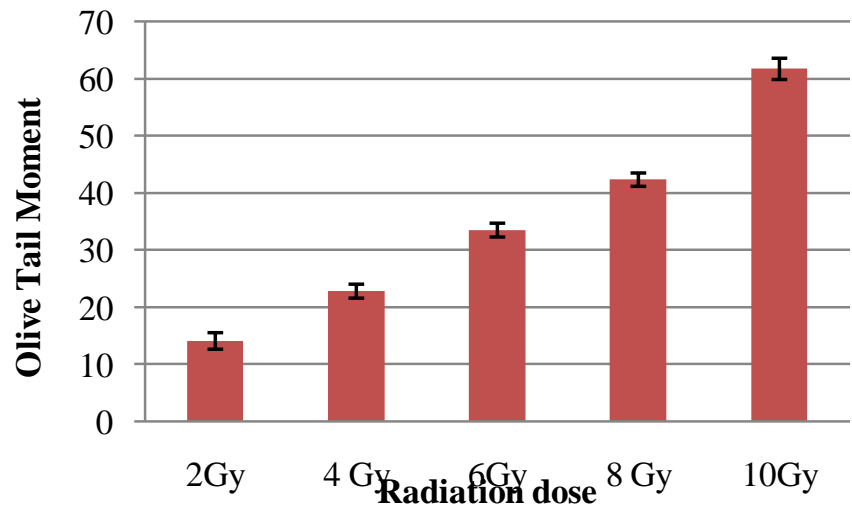

Fig. 2: Degree of DNA damage in cultured lymphocytes after exposing to different doses of radiation. $(\mathrm{P}<0.05)$.

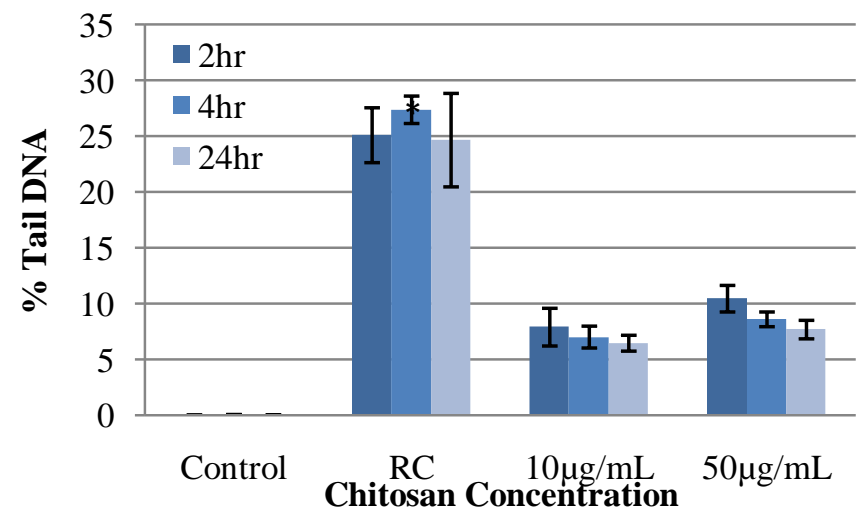

Fig. 3: Degree of DNA damage expressed in Percentage Tail DNA treated with different concentration of chitosan extract and then exposed to radiation. $(\mathrm{P}<0.05) . * \mathrm{P}<0.001$

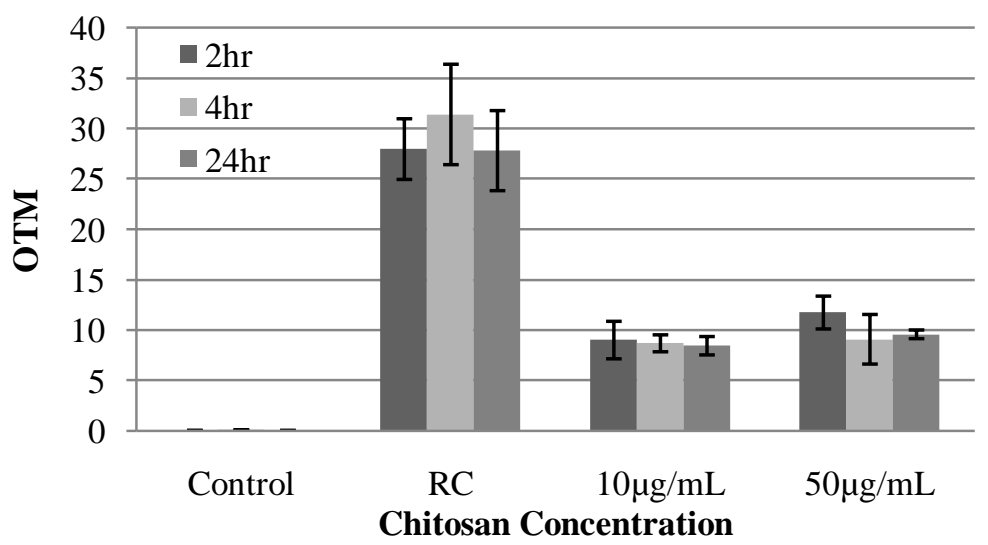

Fig. 4: Degree of DNA damage expressed in OTM treated with different concentration of chitosan extract and then exposed to radiation. (P $<0.05$ ).

Table 5: Percentage of apoptotic cells when lymphocytes were pre treated with chitosan.

\begin{tabular}{|c|c|c|c|c|}
\hline & Untreated & Radiation Control & $10 \mu \mathrm{g} / \mathrm{mL}$ & $50 \mu \mathrm{g} / \mathrm{mL}$ \\
\hline $2 \mathrm{hr}$ & $0.56 \pm 0.14$ & $27.22 \pm 0.87^{*}$ & $20.43 \pm 3.83$ & $21.62 \pm 2.86$ \\
\hline $24 \mathrm{hr}$ & $0.91 \pm 0.09$ & $33.87 \pm 0.34 *$ & $17.60 \pm 4.01$ & $20.71 \pm 5.34$ \\
\hline
\end{tabular}

Table 6: Percentage of Micronucleated cells when lymphocytes were pre treated with chitosan

\begin{tabular}{cc}
\hline Concentrations & Percentage of Micronucleus Formation \\
\hline Untreated & $2.14 \pm 0.13$ \\
Radiation control & $14.50 \pm 0.79$ \\
$\mathbf{1 0} \boldsymbol{\mu g} / \mathbf{m L}$ & $7.63 \pm 1.02$ \\
$\mathbf{5 0} \mathbf{\mu g} / \mathbf{m L}$ & $8.75 \pm 0.93$ \\
\hline
\end{tabular}

$\mathrm{P}<0.05$.

Table 7: Percentage of cell viability when lymphocytes were pre treated with chitosan.

\begin{tabular}{|c|c|c|c|c|}
\hline & Untreated & Radiation Control & $10 \mu \mathrm{g} / \mathrm{mL}$ & $50 \mu \mathrm{g} / \mathrm{mL}$ \\
\hline $2 \mathrm{hr}$ & $97.00 \pm 2.00$ & $76.34 \pm 1.23$ & $88.92 \pm 6.43$ & $85.47 \pm 9.03$ \\
\hline $24 \mathrm{hr}$ & $98.14 \pm 1.10$ & $75.98 \pm 1.98 *$ & $91.63 \pm 4.72$ & $89.52 \pm 4.19$ \\
\hline
\end{tabular}

$\mathrm{P}<0.05$ was considered statistical significant. ${ }^{*} \mathrm{P}<0.001$

\section{DISCUSSION}

Considerable efforts have been committed to explore the possibility of plant products and extracts, as well as synthetic drugs, to reduce the undesirable effects of ionizing radiation. However, several prospective compounds have failed to pass the shift from bench to bedside because of unacceptable behavioural toxicity and side effects (Landauer 1992, Monig 1990, Devi 1998, Durante 2008). So the present study evaluated the lethal dose of chitosan and its protective effect on irradiated lymphocytes. It is well known that the modifications in DNA by ionizing radiation are due to the formation of free radicals which leads to cell killing, mutagenesis, transformation and carcinogenesis. It is level-headed to assume that the agents capable of scavenging free radicals would play a significant role in modulating these processes. Radical scavengers can efficiently protect the cells toward DNA strands breakage. In this study, the effect of chitosan was assessed in vitro using human peripheral blood lymphocytes. Chitosan has 
reported for its free radical scavenging or metal chelating activity by donation of hydrogen or the lone pairs of electrons (Xie et al., 2001, Lin et al., 2009). The interaction of chitosan with metal ions could involve several complex actions including adsorption, ionexchange and chelation (Onsosyen et al., 1990). The hydroxyl groups $(\mathrm{OH})$ and amino groups $\left(\mathrm{NH}_{3}\right)$ in chitosan are the key functional groups for its antioxidant activity. Amino group containing compounds are well known for its radioprotective property (Brown 1967, Madhu et al., 2014). The present study reports shown, a reduction in the DNA damage in chitosan treated group when compared to radiation alone group. Percentage of tail DNA was reduced almost $60 \%$ in $50 \mu \mathrm{g} / \mathrm{mL}$ chitosan treated group. The frequency of EBR induced micronucleus formation was reduced exactly to its half. Number of apoptotic cells were significantly $(\mathrm{P}<0.05)$ declaimed in chitosan treated group. The sign of reduction in the DNA damage is responsible for radioprotection of lymphocytes against EBR effect (Sukanya et al., 2013). Similar findings observed in the present report which conclude the protective effect of chitosan against electron beam induced clastogenic effects.

\section{ACKNOWLEDGEMENT}

The authors express their gratitude to Board of Research in Nuclear Sciences (BRNS), Government of India, for their financial support [2011/34/21/BRNS]. Authors like to thank all the staff members of Microtron Center, Mangalore University, Mangalore, India for providing the radiation source and also extended thanks to Nitte University for providing laboratory facility to carry out this study.

\section{REFERENCES}

Brown PE. Mechanism of action of aminothiol radioprotectors. Nature 1967; 213(5074): 363-364.

Cherupally KKN, Dillip K, Parida and Taisei Nomura. Radioprotectors in Radiotherapy Journal of Radiation Research 2001; 42: 21-37.

Devi PU. Normal tissue protection in cancer therapy: progress and prospects. Acta Oncol. 1998; 37: 247-252.

Durante M. Physical and biomedical countermeasures for space radiation risk, Z. Med. Phys. 2008; 18: 244-252.
Fenech M, The in vitro micronucleus technique, Mutat. Res. 2000; 455: 81-95.

Jagetia GC, Baliga MS, Malagi KJ, Kamath M. The Evaluation of the Radioprotective Effect of Triphala (an Ayurvedic rejuvenating drug) in the mice exposed to radiation. Phytomedicine 2002; 9: 99-108.

Landauer MR, Davis HD, Kumar KS, Weiss JF. Behavioral toxicity of selected radioprotectors. Adv. Space Res. 1992; 12: 273-283.

Lin SB, Chen SH and Peng KC. Preparation of antibacterial chito-oligosaccharide by altering the degree of deacetylation of $\beta$-chitosan in a Trichodermaharzianumchitinase-hydrolysing process. Journal of the Science of Food and Agriculture 2009; 89(2): 238-244.

Madhu LN, Suchetha Kumari N. Radioprotective effect of sulphydryl group containing triazole derivative to modulate the radiationinduced clastogenic effects. Research in Pharmaceutical Sciences 2014: 9(1): 23-29.

Madhu LN, Suchetha Kumari N, Sarojini BK. Radioprotective effect of 4-amino-4H-1,2,4-triazole-3-thiole against electron beam radiation induced Biochemical and Clastogenic effect. Journal of Pharmacy Research 2014; 8(3): 400-404.

Monig H, Messerschmidt, Streffer C, Scherer E, Streffer C, Trott KR. Chemical Radioprotection in Mammals and in Man. Radiation Exposure and Occupational Risks. Springer-Verlag, Berlin. 1990; 97-143.

Onsosyen E and Skaugrud O. Metal recovery using chitosan. Journal of Chemical Technology and Biotechnology 1990; 49(4): 395-404

Ruiz Herrera T, Ali Khateeb NAA. Production properties and some new applications of chitin and its derivative. Food Sci. 2003; 43: $145-171$

Singh NP, Rapid communication a simple method for accurate estimation of Apoptotic cells. Experimental Cell Research 2000; 256: 328 337.

Tice RR, Andrews P, Hirai O, Singh NP. The single cell gel (SCG) assay: an electrophoretic technique for the detection of DNA damage in individual cells. AdvExp Med Biol. 1991; 283: 15764.

Xie W, Xu P and Liu Q. Antioxidant activity of water-soluble chitosan derivatives. Bioorganic and Medicinal Chemistry Letters 2001; 11(13): 1699-1701.

\section{How to cite this article:}

Shama Rao, Sukanya Shetty, Suchetha Kumari Nalilu, Madhu LN. Radioprotective Properties of Chitosan on Cultured Human Lymphocytes against Electron Beam Radiation. J App Pharm Sci, 2015; 5 (08): 147-151. 